\title{
Toothless Rhetoric or Strategic Polemic? A Textual and Contextual Analysis of Japan's Hate Speech Law
}

\author{
Richard Powell ${ }^{1}$ D
}

Accepted: 9 January 2022 / Published online: 14 February 2022

(C) The Author(s), under exclusive licence to Springer Nature B.V. 2022

\begin{abstract}
In May, 2016 the Diet passed a law on the "Promotion of efforts to eliminate unfair discriminatory speech and behaviour against people originating from outside Japan", widely referred to as ヘイトスピーチ法 (Heito Supiichi Hō /Hate Speech Law). For some residents of Japan it had been a long time coming. Without any laws specifically prohibiting racially discriminatory speech or writing, aggrieved parties had hitherto been forced to resort to indirect lines of protection. In 1999, for example, a Brazilian national ejected from a jewelry shop displaying a poster saying "No foreigners allowed" obtained a favourable ruling citing Japan's ratification of the International Convention on the Elimination of All Forms of Racial Discrimination; and in 2013 an injunction for defamation and obstruction of business was granted on behalf of a school for children of North Korean descent repeatedly subjected to provocative demonstrations. But others questioned the need to reinforce limits on freedom of expression even in the face of aggressive taunts, with some claiming that incidents of racial discrimination in Japan lacked the historical, entrenched and violent dimensions that had prompted hate speech laws in Europe and elsewhere. When the text of the proposed law became public there was also debate about its utility as such an abstract measure seemed inapplicable to many potential victims and lacked punitive sanctions. Against this criticism it could be argued that the law went about as far as the government could expect to go if it were to get it passed; that it appears to be curtailing a particularly aggressive form of hate speech; and that it has ushered in a number of more specific initiatives, especially at local level. This study will begin with the 2016 text itself, drawing on the semiotic framework of Systemic Functional Grammar to explore how it prioritises general principles over specific regulations. This textual analysis will be followed by a contextual account of why the Law was constructed as it was, how it has influenced awareness of hate speech, and where it fits in with an existing genre of non-coercive legislation in Japan.
\end{abstract}

Keywords Hate speech · Japan · Persuasive legislation · Systemic functionalism

Richard Powell

richard.powell@nihon-u.ac.jp

1 Nihon University, Kanda Misaki-cho 1-3-2, Chiyoda-ku, Tokyo 101-8360, Japan 


\section{Aims and Approach}

The Law on the Promotion of Efforts to Eliminate Unfair Discriminatory Speech and Behaviour against Persons Originating from Outside Japan (本邦外出身者 に対する不当な差別的言動の解消に向けた取組の推進に関する法律) [1], referred to widely in Japan, and henceforth in this article, as the Hate Speech Law (Heito Supiichi Hō) or Hate Speech Elimination Act, was passed on May 25, 2016 after extensive debate within and beyond the National Diet that pitted those prioritising the safety and dignity of minority groups against those prioritising freedom of expression. The government-sponsored measure that was passed was somewhat weaker than a failed Opposition proposal and has been criticised for a lack of specificity about what constitutes hate speech [2] and characterised as resembling a policy speech more than a law [3]. Yet there is some evidence that it has helped reduce racist demonstrations despite its lack of punitive provisions [4].

What follows has two main aims. First, in order to examine the Law's abstract and symbolic orientation there will be an analysis of its propositional content, its stance towards perceived readers, and its cohesive composition. Second, to explore how such a rhetorical text emerged and why it nevertheless appears to have influenced public behaviour there will be an account of surrounding sociopolitical and legal contexts. If we consider the text's linguistic features in light of debates on racial discrimination and freedom and a tradition of persuasive legislation, the 2016 measure can be seen as something more than mere human rights window-dressing. And while it is difficult to envisage a stronger law being passed unless there is greater political commitment to minority rights, textual and contextual discourses emerging from the law seem to have led to greater awareness of hate speech issues at the national level and more specific administrative action at local level.

The study begins with an overview of the meanings embedded in the 2016 Law within the trinocular framework of Halliday's Systemic Functional Grammar (SFG). While there is insufficient space for close analysis, the aim is to highlight lexical, pragmatic and structural features that give it the quality of a policy statement. SFG has been chosen as the main conceptual approach here because of its view of language as a social resource for creating meanings and its prioritisation of the sociocultural function of lexicogrammatical choices. Drawing on Malinowsky's theory of the context of situation, Halliday viewed texts as "continuous processes of semantic choices" [5: 10] best understood in reference to the sociocultural system in which they are produced, a position that has been highly influential on Critical Discourse Analysis, where a multifunctional investigation of text, discursive practice and social practice is applied [6: 135-136] to shed light on opaque meanings.

SFG has been applied to the analysis of many languages, with Halliday himself focusing on Mandarin to test out his early ideas, but its comprehensive application to Japanese is relatively recent (e.g. Teruya, 2004, 2007; Thomas, Fukui \& White [cited in 7:2-3]). In the legal domain, Chik has built on studies contrasting 
the high reader-responsibility of Japanese texts with the relatively high writerresponsible tendency of English equivalents to compare the ideational meanings of Japanese and English corporate legal discourse, concluding that the former favours nominalisation and relational processes more than the latter and is consequently less explicit about agency [7: 7].

There has been a steady trickle, though certainly no flood, of interest in the potential of SFG for analysing legal discourse. Bhatia [8: 44-45], a pioneer in the sociolinguistic study of legal texts, acknowledges its influence on genre analysis while calling for greater clarity in its theorisation of genre and register. Martin [9], the leading figure in the Sydney School of SFG since the demise of Halliday, has applied it to the analysis of justice forums. In this section there will be a broad description of the 2016 text based on SFG's attention to three aspects of communication: the Ideational metafunction, which investigates how words and structures (lexicogrammar) represent the propositional content of a text and the interactions among human and non-human phenomena; the Interpersonal metafunction, which explores how relationships between writers and readers (or speakers and listeners) are constructed; and the Textual metafunction, which examines how texts are organised into cohesive discourses. Where SFG terms have a specific meaning when applied to metafunctional analysis that may differ from their more general sense they have been capitalised. Hence the term Textual is capitalised wherever it refers to analysis of the text's organisational and cohesive features, but not when it refers to general analysis of a text in contrast to its contexts.

As a "theory of meaning as a choice" that prioritises paradigmatic over syntagmatic analysis [10: xiv], Halliday's conception might be expected to emphasise individual agency, yet its approach is primarily sociocultural and semiotic. Thompson [11: 9] argues that choice need not imply conscious decisions by speakers and writers so much as access to a range of lexicogrammatical options. Some choices may be subconscious or dictated by institutional practices. Indeed the drafting of public laws may be assumed to be heavily constrained institutionally.

\section{Textual Analysis of 2016 Law}

Despite its general recognition as a law about hate speech, no mention of this term is made in its lengthy title- "Promotion of efforts to eliminate unfair discriminatory words and behaviour against people originating from outside Japan” (本邦外出身 者に対する不当な差別的言動の解消に向けた取組の推進に関する法律)一nor anywhere else in the text, which is short, at just over 12,000 Japanese characters (for rough comparison its provisional English translation contains under 1000 words). It comprises a table of contents, a two-paragraph preamble, seven articles and a supplement.

In addition to the Japanese text (Online Appendix 1) the Ministry of Justice offers an English translation but it describes this as provisional and directs readers to the original. This has been appended for reference (Online Appendix 2), but as it lacks legal force and prioritises cohesive English legalese over close shadowing of the Japanese, only the original is discussed here. Except when illustrating specific 
features of certain clauses I have avoided close translation as structural differences between Japanese and English would produce cumbersome texts requiring further explanation. Instead I will give a summary of the Law's propositional content here.

The Preamble begins by drawing attention to recent occurrences of unfair discriminatory speech and behaviour targeting people originating outside Japan and their descendants and refers to the personal suffering and social rifts this has caused. It adds that such behaviour should not exist and will not be tolerated, in view of Japan's international position. It states that the Law will spread public awareness and cooperation and strengthen efforts to eliminate discriminatory speech and behaviour. Art.1 reiterates the importance of the problem, setting out principles for seeking to eliminate it and also the responsibilities of the government. Art. 2 defines 'unfair speech and behaviour' as inciting the exclusion of 'lawfully resident' people through egregious insults that work to the detriment of their life, body, freedom, reputation or property. Art. 3 sets out the underlying aim of furthering the public's understanding of the need to eliminate such behaviour.

Art. 4 declares the government's responsibility to implement measures to eliminate this behaviour and to give advice in support of efforts by local authorities, while stating that local authorities are to take measures in accordance with local conditions and an appropriate division of labour with the national government. Art. 5 states that the national government will develop systems to prevent disputes related to this problem and offer consultation, while local authorities will also engage in consultation in accordance with local conditions and the division of labour with the national government. Art. 6 states that the national government is to implement educational activities to tackle the problem while local authorities strive to make necessary efforts, again while taking into account the labour division with the national government. Art. 7 is similar but refers to awareness-raising activities rather than education.

A supplementary provision states that the law will come into force upon promulgation and adds that subsequent reviews are to be conducted where necessary and depending on the situation.

\subsection{Ideational Features}

The Ideational dimension of SFG-based analyses is concerned with two closely connected aspects of a text: the experiences and events conveyed within clauses, loosely summarised as who does what to whom, how, when and where (and hence often labelled the Experiential metafunction); and the construction of clause complexes through patterns of dependency and prioritisation, known as the Logical metafunction. Experiential analysis involves identifying Participants (generally corresponding to nouns, pronouns or nominal groups) categorised as Actors, Behavers, Beneficiaries, Carriers, Goals, Ranges, Sayers, Sensors or Tokens, according to their function. The Processes that link them (corresponding to verbs) are classified as Material, Mental, Relational, Behavioural, Verbal or Existential. The Circumstances under which Processes occur typically correspond to adverbs and adverbial phrases. Thus an Actor is a Participant engaged 
in a Material Process (e.g. an action or movement) that usually involves a Beneficiary or a Goal, while Mental Processes, such as knowing or thinking, typically have a Sensor on one side and a Phenomenon on the other. These categories are essentially grammatical rather than semantic (Halliday [12: 112]), even though they are concerned with the function of linguistic choices rather than the internal logic of linguistic structures that is the focus of Universal Grammarians. Hence transitivity involving non-material components may be treated as Material Processes inasmuch as there is movement from one Participant to another. Adjectives and adjectival phrases are classed as Attribute Relational Participants since they index identities or qualities. By highlighting linkage between Participants and Processes, Ideational analysis may also draw attention to agency.

The features emerging from a text through Ideational analysis correspond to the context of field, i.e. the social process as described in terms of what is going on. The text in question, for example, was constructed within a legislative field, which typically has a regulatory function. Readers familiar with a certain field tend to expect certain kinds of participants and processes more than others and may be struck by deviations, although expectations will vary according to local legal practices as well as cultural preferences shaping the selection of the linguistic resources offered by the source language.

Although analysis can be applied at any level, it typically operates at clause level, with the logical relationship among clauses further described in terms of Taxisparatactic clauses having an equal relationship and hypotactic clauses a dependent one. Hypotaxis emerges in different ways according to the grammatical resources of a given language. In Japanese, for example, subordinate clauses may be marked finally by words corresponding to conjunctions such as 'although", 'because' and 'when' that are normally clause-initial in English, while prenominal modifying clauses are used rather than relative clauses. Hence the title of the 2016 Law places 本邦外出身者に対する ('against people originating outside the nation'), 不当な 差別的言動の解消に向けた('aiming at the elimination of unfair discriminatory speech behaviour'), and 取組の推進に関する('regarding the promotion of efforts') all before the noun 法律(law). Moreover, Japanese verbs, which are usually clausesfinal, typically take medial morphology (loosely corresponding to English present participles) except for in the main clause (which is usually final in a clause complex). This may produce strings of clauses ending in medial verbs that appear to be paratactic in the absence of subordinating conjunctions yet show relationships of dependency.

In the 2016 Law we can identify 158 Participants, of which $18 \%$ of the total (28 instances) refer to people, the nominal group 'residents from outside Japan or their descendants’ (出身者又はその子孫) comprising 22 of these 28 personal Participants, or $14 \%$ of the total Participants, and 'citizens' or 'residents' making up most of the rest. The nominal group 'unjust discriminatory speech and behaviour' (出身 者又はその子孫) also constitutes $14 \%$ of total (22). Next in frequency are institutional Participants ('the nation', 'local authorities'), at 12\% (19), followed by 'law', 'provision' or 'article' at $11 \%$ (18) and 'initiatives' or 'measures', also at $11 \%$ (18). ‘Actual conditions' (実情) and ‘education' (教育) each appears five times. Covering two thirds of participants, this information alone gives us some idea of who is doing 
what to whom. Four instances each of 'understanding'(理解), 'role division' (役割 分担), 'local area' (当該地域) and 'community/society' (社会) among the remaining participants, and three appearances of 'necessity', 'consultation' and 'monitoring', add to a picture of official engagement with discriminatory practices.

A focus on the Processes linking these Participants helps to clarify the nature of this engagement. With $71 \%$ of the Processes Material ones, there is a sense of things being done, rather than merely stated or felt-although analysis of Interpersonal meanings will show the extent to which action is hedged or even avoided. 'Implement' (実施する) appears six times among the Processes, 'carry out' (行 う), ‘respond' (応ずる) and ‘strive’ (努める) five times each, and 'deepen' (深め る) four times. Near-similes corresponding to 'incite' also appear five times. 'Implement' is found twice in the same clause cluster as 'country' (国) and twice with 'local authority' (地方公共団体), but also occurs twice without an explicit agent, while 'carry out' is associated twice with the country and twice with local authorities but also appears once without an agent. 'Respond' is found twice with 'country', four times with 'local authority' and once without an agent. 'Strive' is linked once to 'country', three times to local authorities, and once without an agent. Each could arguably be regarded as a Mental Process, depending on what action is implied.

Just nine Processes fall clearly into the Mental category (13\% of the total), of which the most frequent is 'take into account' (踏まえる) with four instances, all having 'local authority' as the agent and referring to the division of roles with the national government. Most of the five Verbal Processes— 'refer' (いう, used twice), 'announce’ (告知し), ‘clarify’ (明らかにする) and ‘declare (宣言する)—are concerned with positioning the text itself. Different forms of the copula である make up six instances of Relational Processes corresponding to 'be', with one Existential use of the same verb ('should not exist').

There are very few Circumstances to indicate where, when, how or why the transitivity among Participants flows. The Preamble opens with 'In our country“ (我が 国において) followed by ‘in recent years’ (近年), and the Supplementary Provisions state that the Law will come into effect from the date of publication (公布 の日から). Among the seven articles themselves, 'outside the country' (本邦の域 外or本邦外) appears 20 times, but always embedded in a nominal group describing residents of overseas origin rather than as andication of where something is happening.

The frequency of legal and administrative lexical items such as 'country', 'local authority', 'law' and 'provision', is consistent with the legal field but ParticipantProcess linkage here evokes the abstract and rhetorical nature of constitutions more than that of enactments. The country emerges as a key player, supported by local authorities. People originating outside the country are always positioned as recipients of unfair and discriminatory speech behaviour, with little detail about the nature or agents of this behaviour. The dominance of Material Processes suggests things are to be done, but there is a dearth of information about where, when or how, with education, consultation and monitoring implying didactic and supervisory rather than regulatory action.

The relationship among clauses reinforces this initial impression of vagueness. There is little explicit hypotaxis, with only three clauses linked purposively (e.g. in 
Art. 4: 'The government (...), in order to promote measures by local governments to eliminate unfair discriminatory behaviour (...), has the responsibility of giving advice and taking other measures). The most common pattern of linkage has implied rather than explicit hypotaxis in which a series of clauses ending in medial verbs, or the conjunction とともに ('together with'/ 'while'/ 'as') precede a main clause. The preamble, for example, ends with:

ここに、このような不当な差別的言動は許されないことを宣言するととも に、

Hereby, while declaring that such unjust discriminatory speech and behaviour cannot be permitted,

更なる人権教育と人権啓発などを通じて国民に周知を図り、

making citizens aware through further human rights education and human rights inculcation

$$
\text { その理解と協力を得つつ、 }
$$

and obtaining understanding and cooperation

不当な差別的言動の解消に向けた取組を推進すべく

and necessitating the promotion of efforts to eliminate unfair discriminatory speech and behavior

$$
\text { この法律を制定する。 }
$$

this law is enacted.

The unnaturalness of my translation above, drafted to highlight how final clauses are preceded by clauses ending in medial verbs without explicit hypotactic markers, should not be taken to reflect unnaturalness in the Japanese, where a degree of dependency in the preceding clauses is implicit. But it should be noted that the drafters have chosen not to draw on a repertory of conjunctions available to express causal, conditional or temporal relations more explicitly. The pattern of stringing vaguely subordinate clauses before statement also serves to emphasise the purpose of the law or the plans of the government and local authorities as stated in final clauses.

As for lexical choice, it should be noted that one of the key terms in the Law, 言 動 (gendō), while rendered in the Ministry of Justice's provisional translation and in most English-medium commentaries of the enactment as "speech and behaviour" and hence translated accordingly here, carries considerable ambiguity about the relationship between its two elements and what they cover. Among the five example sentences offered by the online dictionary Jisho.org the term is equated variously with 'talk', 'behaviour or action', and 'actions and words' [13]. NTT's Resonant dictionary search portal defines the term as 'such things as human sayings and doings' [14].

\subsection{Interpersonal Features}

Where Ideational analysis aims to explore what is going on, Interpersonal analysis considers linkage among writers, readers and third parties in terms of power, knowledge, familiarity, solidarity and politeness, along with stances toward the content being proposed. The way writers construct the tenor of a text through devices such as verb modality and politeness choices, for example, reflects their assumptions 
about readers. As might be expected of legislation, the tenor is formal and lacks direct reference to the writer or reader, but we can find evidence of solidarity strategies in lexical items such as 我が国 (waga kuni 'our country'-rendered in the provisional translation as 'Japan'), in contrast to the targets of hate speech, who are introduced as 'lawfully residing' (適法に居住する) while repeatedly referred to as from outside the country (本邦の域外or 本邦外).

The tenor of a text is marked most clearly in finite clauses involving a Subject (typically a noun or nominal group) and a verbal group, the latter involving mood choices (imperative or indicative; declarative or interrogative). Other clauses (which usually follow the finite clause in English but precede it in Japanese) are termed Residue as they tend to carry less Interpersonal information, and this may be particularly so in Japanese as medial verbs generally lack tense- or politeness-marking. The 2016 Law has 18 finite clauses, none of them interrogative, with all but two of these 18 declarative clauses in affirmative form. Only two have negative polarity, one expressing a critical stance: 〜ふさわしいものではない('is not appropriate', referring, in the Preliminary, to the overlooking of hate speech); and one expressing obligation: 〜寄与するように努めなければならない('must strive to contribute’ in Art. 6).

All the final clauses are in the present tense. However, in Japanese the present normally stands in for the future too, so the aspectual, modal and semantic dimensions of the verbs, in addition to the surrounding context, must be considered in determining time frames. We can see a shift from present to future orientation as the text progresses, with the Preamble describing events continuing from the recent past ('is/has been causing serious rifts'-the only use of the continuous form) and the opening articles defining terms and stating obligations, all in the present time frame, followed by a shift to future commitment from Article 4 in order to declare what the relevant authorities will do, or strive to do. The future is also implied in the Supplementary Provisions, which deal with the Law coming into effect and subsequent monitoring.

It is notable that in contrast to the single instance of strong obligatory modality in Art. 6, nine of the 18 finite clauses use the construction ものとする mono to suru, e.g. Tōgai chiiki no jitsujō ni ōjita shisaku wo kōzuru yō tsutomeru mono to

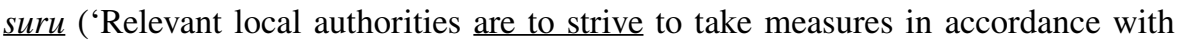
actual circumstances'). This form is generally assumed to imply lower obligation than the ならなければならないnaranakerebanaranai used in Art. 3 and it has been argued that its prevalence gives the text attenuated instrumentality [15]. The Kokoro Group legal consultancy advises that the term does imply some obligation, if weaker and more general than naranakerebanaranai, and is frequently found in connection with administrative institutions [16], so it may be significant that wherever mono to suru is used in the 2016 Law, the subject of the verb it modifies is either 国 ('country'/'national government') or 'local authorities', except in a Supplementary Provision about future monitoring that lacks any explicit subject. This nuanced degree of obligation is especially notable where the form is used with the verb tsutomeru (strive or endeavour), as in Arts. 4 and 5, which refer to the role of local authorities. However, we also need to consider institutional drafting practices before drawing conclusions about the degree of commitment embedded into the text, 
and it is worth noting that the provisional translation of the Law renders this construction as 'shall', which is a prevalent indicator of obligation in English legalese.

While the obligatory tenor may be softened, the text does not avoid agency, with just one passive form found in the finite clauses (in the closing reference about monitoring), and three instances in medial clauses, all in the Preamble, describing unjust discriminatory speech and suffering endured by minorities before declaring that it will not be tolerated. Kuni (nation/government) occurs frequently as the subject of a finite clause, and 'local authorities' is also positioned four times as Subject, kokumin (citizens) only once. But with more than twice as many medial as finite clauses most of the official activity is not only vaguely worded but also sidelined from discussion.

In addition to aspect, tense, voice and modality, final verbs in Japanese are marked for politeness. In the 2016 Law all are in the plain form, which is the default for public laws, as well as for newspapers and other texts directed at general readerships (even though more polite forms are increasingly used for documents addressing more specific groups such as the students or employees). The only Mood Adjuncts (evaluations and comments) are the adverbial phrase もとょり ('obviously') in the Preamble, which assumes readers share the writer's repugnance about hate speech, and the adjective ふさわしい ('appropriate'), used with negative polarity to condemn hate speech in the same section. But there are also several reinforcing lexical items that indicate appraisal, including 不当 ('unjust') which is always attached to 'discriminatory speech' (thus creating space for the possibility of just discrimination), 深刻 ('acute'), used in the Preamble to emphasise social instability, and 喫緊 ('urgent'), used in Art.1 to emphasise the need for action.

Japanese writers have a degree of choice when it comes to script, and a number of words that might have been written in Sino-Japanese characters, such as 相応しい (fusawashiil 'appropriate'), have been written in phonetic hiragana (ふさわしい). Further, the character 煽, which means 'incite' when in the combination 煽動, has phonetic furigana added to it to aid readers, even though it is in the list of Joyyo Kanji that junior high school students are expected to master. These choices suggest the text is intended to be accessible to a wide audience.

\subsection{Textual Features}

Textual features comprise organisational choices made by writers, such as the lexical density, lexical chains, grammatical complexity, repetitions, ellipses and breaks that give a text its communicative quality, i.e. its mode, thereby enabling Ideational and Interpersonal meanings to combine into a coherent message.

SFG-based analysis assumes message-makers draw on multiple choices in conveying propositional content, even when these are not made consciously or freely. When it comes to legislative drafting it is likely that some features, such as layout and schematic stages, will be relatively restrained by institutional requirements. Hence the 2016 text is unmistakable as a piece of Japanese legislation. Its headings, preamble foregrounding the legislation, series of articles, and supplementary provisions pointing toward the future constitute near obligatory elements to be found in Japanese legal texts whether they are written horizontally, as in the version from 
the Ministry of Justice website appended here, or vertically and from right to left, which is the preferred format of Kanpō [17], the government's official gazette. In other areas, however, there may be room to emphasise parts of the content or direct readers through certain lines of argument. SFG pays particular attention to thematic structure when analysing arguments, seeing messages as structured at clause level through the introduction of a Theme, or 'point of departure' [18: 64] containing given information that sets up a context to be developed in a Rheme (elaboration or new information). As in English, Themes in Japanese are clause-initial, and the task of deciding where the Theme leaves off and the Rheme proceeds is often made easier by the use of the topic marker $w a$, which more often than not refers to a subject but could also be an object or an adverbial phrase: indeed we can assume that the thematisation of a textual component that might more usually constitute part of the Rheme indicates a decision to mark it.

In the 2016 Law we can identify 19 Themes, two of them further divisible into a textual and topical theme: 'In our country' (Waga kuni ni oite wa) + 'In recent years, legally resident persons or their descendant, by reason of their overseas origins' in the opening of the Preamble; and 'In this law' (Kono hôritsu ni oite) + 'what constitutes unfair discriminatory speech behaviour toward those originating overseas' and Art.2. 'Overlooking such behaviour', 'Through further human rights education and awareness-raising', the comment 'Obviously' and the textual marker 'Here' are also thematised in the Preamble, and 'Regarding efforts to eliminate discriminatory speech and behaviour' is thematised in the final Supplementary Provision. All the other Themes refer to the country/national government, the local authorities, or the new law itself-although in Art. 5, Kuni (country) is implicitly carried over from the previous clause, so the Theme could also be regarded as 'Depending on the local situation'. Through this thematic chain a discourse about the significance of the law, the national government and the local authorities is constructed, with the Rhemes containing details about duties and proposed activities.

The discourse is also shaped by extensive repetition, with the nominal groups 'residents originating outside Japan or their descendants' and 'unjust discriminatory speech and behaviour' each occurring 22 times and kuni, functioning either as 'nation' or as 'national government' occurring 13 times, followed by nine instances of 'initiatives' and six of 'local authorities', 'law' and 'measures'. In contrast, in describing the nature of discriminatory speech and behaviour there are only two mentions of attempts to exclude (排除) certain residents, and just one mention each of their harm (危害) and suffering (苦痛).

\section{Summary}

Attention to the Ideational, Interpersonal and Textual features of the 2016 Law brings support for the view that it is rhetorical rather than substantive, aiming to show that the government are launching measures to counter an urgent and important social problem, and calling on citizens and especially local authorities to cooperate, but without specifying what is to be done and with little detail about what particular kind of speech and behaviour is targeted. What is clearer is that such action as 
is to be taken will be on behalf of lawful residents originating outside Japan, which suggests that undocumented foreigners, and also indigenous minorities (such as ethnic groups based in Hokkaido and Okinawa or sociocultural, economic and sexual minorities) are not covered. Moreover there is nothing in the Law about penalties. With an appeal to social harmony and national pride, the emphasis is on raising awareness of conduct described as unacceptable to a nation of Japan's standing and addressing the problem through educational measures initiated by the authorities in tandem with public cooperation. The text is short and repetitive, as well as lacking in substance. But it does envisage the possibility of further action after monitoring the effects of the new law.

\section{Contextual Analysis of 2016 Law}

Although this account proceeds from text to context rather than the other way round and attempts to leave space for alternative interpretations, it goes without saying that no textual analysis can be devoid of prior assumptions about which contextual factors have particular influence, and the analysis above was informed by academic and journalistic commentary on the political difficulties of getting punitive measures against nationalist groups approved by a largely conservative Diet, together with evidence that the judiciary is better disposed toward restricting freedom of expression if it threatens government stability or the material and social well-being of specific individuals than if it harasses minority groups. Another factor assumed to have influenced the Law's construction is Japan's tradition of administrative guidance (行政指導 gyōsei shidō), whereby authorities seek to transform social behaviour by referencing civic duty rather than by imposing legal penalties.

In a recent article on the impact of derogatory language on intergroup contempt, Bilewicz and Soral [19] claim hate speech has risen by stealth in the last twenty years, strikingly evinced by the increasing willingness of politicians themselves to slip into it. Japan's 2016 Law presents discriminatory speech and behaviour as a recent phenomenon, yet even without exploring the likelihood that ethnic discrimination has existed in Japan, as anywhere else, for a long time, the behaviour that the legislation appears to have most in mind cannot be explained without reference to Japan's colonial past. Its positioning as a problem calling for legislation may nevertheless owe more to political and technological developments in the last two decades or so.

Japan is far from the homogeneous culture that many nationalist narratives portray it as-some going on to refute suggestions that there are racist practices by dint of the claim that there is only one race [20: 1]. But through restrictive immigration policies it has resisted the levels of ethnic diversity typical of most industrialised democracies, and despite steep rises in foreign-born workers over the last two decades as many as $98 \%$ of the population see themselves as native Japanese and a majority remain wary of greater diversity [21]. However, even those regarding migrant labour as a temporary economic fix or disregarding the distinct identities of indigenous minorities such as the Ainu or Okinawans cannot avoid the reality of long-term nationwide cohabitation with one large ethnic minority: residents with 
Korean roots. Taking in the colonisation of the Korean Peninsula in 1910, pogroms during the chaos of the 1923 Great Kanto Earthquake, influxes of both voluntary and forced labour during the militarised period, and the repatriation of hundreds of thousands after the conclusion of the Pacific War, it has often been a strained cohabitation, and remains key to current debates about hate speech.

\subsection{The Influence of Anti-Korean Rallies}

In evolving from an isolated preindustrial country in the later 19th century into an industrialised and militarised colonial power by the early 20th century, Japan found itself juggling two unfamiliar identities: as an outlier among the other global powers, all of which were based in the Christian West; and as a leader and aggressor among its Asian neighbours. Rejecting the idea that Japan was pursuing idealism when, in the face of opposition from Australia and other British dominions and realpolitik on the part of the United States, it unsuccessfully proposed the insertion of a covenant on racial equality in the Charter of the new League of Nations, Shimazu [22: 4] argues that, like the other members of the elite nations it sought to join, the country rode a wave of complex and competing motivations, including universalism, international status, domestic politics, migration policies and conference tactics [22: 5], and that any subsequent debates about human rights that its proposal may have triggered were large unintended [22: 6]. Indeed it would be a stretch to view early 20thcentury Japan as a leader in either racial equality or national self-determination (the other seminal rights discourse at the Paris Peace Conference), given that it had made Korea a protectorate in 1905 and annexed it five years later, thereafter pursuing an assimilationist form of control distinct from the segregationist policies dominating much of the Anglo-Saxon world [23: 66].

Continuous historical movement of Koreans into Japan is well documented, with even the Shōwa Emperor on record as acknowledging the Korean ancestry of the imperial family [24:], but an unprecedented influx came in the wake of Japan's colonisation of Korea, accompanied by an unprecedented excuse for the characterisation of immigration as potentially disruptive. Extrapolating from imperial records and the decennial censuses conducted after 1920, Tamura estimates that Korean residents soared from under 1000 on the eve of annexation to 419,000 in 1939 and 2.2 million by the end of the war [24: 80], the later increases largely accounted for by a shift from voluntary migration to forced industrial and military conscription [24: 83]. Local antipathy rose with the severe economic slump Japan experienced after the First World War, culminating in a massacre of between 6000 and 10,000 Koreans by both civilians and police during the chaos following the 1923 Kanto Earthquake, with the rise of Korean nationalism in protest against the Japanese occupation of their homeland further heightening tensions [24: 82]. Legal status then became problematic in 1945 since Korean subjects of the empire, alongside the Taiwanese, became classified as foreigners. While up to 1.4 million were repatriated after the war, over half a million remained, a figure perhaps peaking at 600,000 in the 1980s [24:84], though Tamura notes that the various legal statuses of people of Korean extraction make counting difficult [24: 88]. While the 1952 San Francisco Treaty removed the voting rights many had held as imperial 
subjects [27: 5], the 1965 Japan-South Korea Treaty granted Japanese permanent residence to those holding or applying for South Korean nationality [24: 79]. Large numbers who had remained effectively stateless received permanent resident status in 1981, and in 1991 long-term residents were granted the status of Special Permanent Resident in compliance with Japan's commitments to the social citizenship rights of non-nationals under the International Covenants on Human Rights and the UN Refugee Convention [25]. While not extending to voting rights, this status has conferred certain benefits not shared by other permanent residents, [27: 6]. Hence special permanent residents were allowed to leave and return to Japan during the first year of the Covid-19 pandemic when other non-citizen residents were barred from returning if they left [26].

Naturalisation has been rising since the 1970s [24: 84], despite its stigmatisation by the two main organisations claiming the allegiance of Koreans in Japan: Mindan, for those aligning with the South; and Chongryun, a North-aligned association whose greater size historically reflected the domination of wartime anticolonial resistance by northern leftists [27: 5] but ebbed as the balance of power on the Korean Peninsula shifted south [28]). While not always readily distinguishable from other long-term residents of Korean extraction, Zainichi ('Japan-resident') Koreans, i.e. those historically established in Japan, remain the largest ethnic minority [24: 78], and many have resisted naturalisation as it involves renouncing claims to Korean citizenship as well as lengthy and costly administrative procedures and intrusive background checks [27: 6].

In addition to historical antagonism, a number of more recent developments have helped raise tensions. The Korean and Chinese republics have long disputed Japanese accounts of the Pacific War and the content of high school history textbooks, and compensation demands for former 'comfort women' forced into institutionalised prostitution, or ministerial visits to the Yasukuni Jinja war-dead shrine, routinely trigger verbal hostility. Moreover the polarising capacity of online social networks in the last two decades has fanned tensions arising from a number of developments, including the rise of an economically successful and more assertive South Korea, the increased propensity of North Korea to use its nuclear arsenal as a political bargaining chip. One computational linguist has traced a surge of South Korean hostility to the use of the Asahi military flag to 2011, when tension over the sovereignty of disputed islands in the Japan Sea/East Sea was soaring [29]. In October, 2018 Japan withdrew from an international fleet review after South Korea objected to its ships flying the naval ensign, which is substantially the same as that flown in wartime, in its waters, with one Korean lawmaker proposing the president attend the event on a vessel bearing the Korean name of disputed islands [30]. Disputes with China can also have repercussions for relations with domestic minorities in Japan, and Chan and Bridges [31: 134-136] draw attention to a dangerous coincidence between the PRC's turn toward nationalism to offset economic instability and the Japanese government's attempts to ramp up patriotism to compensate for perceived economic and political decline. And rather than deflect or diffuse tensions with Japan's Korean residents, tensions with Beijing are if anything more likely to exacerbate them. 


\subsection{Calls for Legislation as a Response to the Rise of a New Far Right}

While discrimination against Korean and other minorities has a long history in Japan, with evidence of the courts adjudicating workplace disputes stretching back more than half a century [32], moves to address discrimination on the level of hate speech has only gathered momentum within the last two decades, shaped primarily by reaction to a new kind of right-wing activism typified by Zaitokukai (an abbreviation of 在日特権を許さない市民の会/Association of Citizens against the Special Privileges of Zainichi). Formed in 2006 by Sakurai Makoto, who now heads Japan First, a new party currently focused on opposing initiatives to grant Zainichi local voting rights, Zaitotukai strives to frame Zainichi as unjust recipients of 'special privileges' that are cast as abuses of the welfare and fiscal systems [27: 11]. Yoon and Asahina [33] emphasise the association's innovative role as a movement that has outflanked the traditional right by popularising formerly stigmatised ultranationalism and taking advantage of the collapse of the traditional left, hence resembling populism in the west. Conversely, Robillard-Martel and Laurent [27: 1-2] stress continuities with historical rightism, highlighting the use of wartime symbols and slogans such as futei senjin ('faithless Koreans') that were hurled around during the 1923 massacres.

The importance of Zaitokukai to the framing of the 2016 Hate Speech Law lies partly in its capacity to publicise racist discourses nationwide, despite a membership of perhaps no more than 12,000 [34], but also in the ferocity of its attacks on specific targets. Though primarily verbal, these have also been accompanied by acts of vandalism, of which the highest profile case is a series of demonstrations between 2009 and 2010 against the Kyoto Korean First Elementary School. These involved the occupation of an adjacent park used by the schoolchildren, cries for the expulsion of Koreans continuously blasted out on loudhailers, and the online distribution of videos of the demonstrations accompanied by calls to participate [35: 58]. One of the slogans repeatedly yelled at the school dubbed it a training centre for North Korean spies [36]. Although the school petitioned Kyoto District Court to prohibit demonstrations within 20 metres of their premises the activity continued, and so in December, 2009 it filed an allegation of obstruction of its operations. In April, 2011 the court ruled that obstruction, as well as criminal damage, had occurred and three members of Zaitokukai were given suspended sentences [35: 59]. The school also filed a civil claim and in October, 2013 the Kyoto District Court awarded an injunction against the association and damages in favour of the school [35: 59].

Although there had been civil judgments in discrimination cases in Japan that referenced the International Convention of Elimination of Racial Discrimination (ICERD), notably that of a Brazilian national who successfully sued a shop in Hamamatsu displaying a notice saying "No foreigners allowed" [37], the Kyoto ruling has been touted as the first to recognise hate speech as an offence. However, Kawanishi emphasises that the court failed to formulate a novel legal concept and merely ruled that Zaitokukai's conduct was not protected by Japan's assertion that that constitutional guarantees about freedom of association and expression remained intact after its ratification of ICERD [35: 61]. While upholding the decision in favour of the school, the Osaka High Court clarified that no general obligation under 
ICERD had been established to regulate relationships between private individuals, though the Convention should be read together with constitutional principles. Moreover, racial discrimination must be shown to cause harm to a specific victim, not merely a group [35: 60-61].

A pair of criminal and civil rulings in Tokushima, Shikoku in 2010 had found members of Zaitokukai guilty of trespass and obstruction of business for demonstrating outside the premises of a teachers' union that had fundraised for a local Korean school, the judgment emphasising the relevance, if not binding authority, of ICERD, and noted Zaiktokukai's use of racist epithets as a tool of incitement [35: 62-63]. The demonstrators had at one point entered the premises, called a (non-Korean) former official of the union a "Koreans' dog" and a 'traitor" and physically harassed her, and shortly before the passage of the Hate Speech Law the courts increased the damages awarded against the defendants, the presiding judge concluding, contrary to the initial judgment, that the behaviour was clearly based on racist ideology, even if its immediate victims were Japanese [38]. But the Kyoto and Osaka rulings of 2013 seem to have been particularly influential on media debate [3: 242], paving the way for many lawmakers to embrace the idea of legislative action.

A bill introduced by an opposition lawmaker in May, 2015 seeking to ban insults, harassment or unjust discrimination directed at group attributes failed to gain sufficient parliamentary support. But a March, 2016 Report by the Ministry of Justice on the continuing problem of hate demonstrations helped persuade the ruling LDP-Kōmeitō coalition to propose its own bill, focusing more narrowly on unjust and exclusionist threats against the bodies, lives and liberty of legally residing nonJapanese [35: 64-5]. The opposition Democratic Party managed to have "egregious insults" added to the description of the targeted behaviour, and the bill passed in May [39].

\subsection{Impediments to Passage of Stronger Legislation}

It is beyond the ambit of this account to attempt to uncover the motives of those opposed to stronger and more comprehensive legislation, but it should be noted that among both lawmakers and lawyers the most prominent arguments for resisting new laws have centred around the sanctity of freedom of speech and the availability of other legal measures, including civil and criminal defamation to deal with verbal attacks on individuals and criminal damage to deal with attacks on property (in the Kyoto school attacks at one point the school's soccer goal was vandalised).

"Liberty of speech, writing, publication, public meetings and associations within the limits of the law" had been guaranteed in Art. 29 of the Meiji Constitution [40], but this was interpreted to allow for extreme levels of censorship and thought control as the country slid into militarism in the Shōwa period. In reaction, provisions in the 1947 constitution, which has never been amended, to protect freedom of thought and conscience (Art. 19) and assembly, association and expression (Art. 21) have been considered beyond negotiation, to the extent that Japan insisted its adherence to the anti-discriminatory provisions of ICERD being remain within the bounds of the constitution [41]. Indeed the first legislative attempt to curb hate speech-toward 
the Burakumin, a subaltern hangover from Japan's feudal caste system-failed largely because of claims that it would restrict freedom of speech, even though the proposal, like the 2016 Law, contained no penalties [3: 239]. While Higaki [3: 242-243] acknowledges that there are legitimate reasons for fearing that a general ban on hate speech could put political criticism in jeopardy, Sato [41] questions the sincerity of rigid applications of Art. 21, given that it has not stood in the way of restrictions on the publication of obscene materials, criminal defamation, or criminal insults. Kotani [45: 605] concurs that the constitution does not necessarily rule out the restriction of hate speech, while cautioning that the highly political contexts in which much of it occurs, especially in relation to Korea and the Korean minority, make judicial and political conservatism in this area advisable.

As for the availability of alternative legal processes, these continue to be used even after passage of the 2016 Law. In 2019, for example, a former head of the Kyoto branch of Zaitokukai who had received a suspended sentence for the 2010 attacks was fined for damaging the reputation of the Kyoto Korean School when delivering a speech at a park next to its former site two years previously in which he accused the school of collusion with the abduction of Japanese citizens by North Korea [42], a topic that, alongside Pyongyang's testing of nuclear missiles, remains one of the bitterest sources of anti-DPKR resentment for many Japanese. However, the defence's attempts to claim that the remarks were directed against Chongryun, rather than specifically against the school, suggest that the idea of hate speech unrelated to specific harm to specific individuals is has still not been fully established in civil law. To cover shortcomings, Sato has proposed that the 2016 Hate Speech Law clarify which groups are to be protected [41]. There is also a recurrent line of argument to the effect that the victims of hate speech can use their own rights to freedom of speech to counter it, rather than turn to criminal law (e.g. [43]). This is an avenue that Lepoutre [44] has explored recently in non-Japanese contexts, arguing that even though there is undoubtedly a power asymmetry between perpetrators of hate speech and victims, informed and pro-active forms of corrective speech may provide an effective counterweight.

\section{The 2016 Law as a Strategic Response to a Particular Kind of Hate Speech}

Reading the text of the 2016 Law in the context of the events leading up to its passage we may conclude that its rhetorical nature is something more than a desire to be seen to be doing something without actually doing very much. In the context of traditional reluctance to restrict speech that aligns Japan more with the United States than Europe-albeit a tradition that has not preempted the censorship of pornography or restrictions on "degrading behaviour' surrounding public elections [46] - the measure has focused on a particular kind of violent behaviour as represented by the activities of bodies such as Zaitokukai, but by implication rather than by singling out the association or its mainly Korean targets. Indeed there is no mention of 'race' whatsoever. But provided they are legally resident the measure is equally applicable 
to the large Chinese minority, against whom rallies were also on the rise at the time of the enactment [3: 240]), but the Law clearly was not framed to tackle discrimination against indigenous groups such as the Ainu, the Okinawans or the Burakumin. However, it should be noted that a supplementary resolution adopted by the Diet stipulates that the wording of the text cannot be interpreted as allowing discriminatory speech against groups not originating outside Japan [47].

Few discussions of the Law have focused on the term 言動 (gendō: speech and behaviour), yet it should be pointed out that this is not the usual wording found in constitutional provisions about freedom of expression, which prefer 言論 (genron: speech, expression). While use of gendō varies, as was argued above (2.1), the term arguably implies something more than mere speech, and if we take Zaitokukai's actions against Korean groups and supporters as a template we can infer that hostile, mechanically amplified speech produced by organised demonstrators accompanied by threats of, and sometimes acts of, violence are what the legislators had in mind. Certainly, it is just this kind of behaviour that was reported to have declined within a year of the Law passing [48]. However, we lack evidence to demonstrate a causal connection and must also consider the effect of local authority measures that have followed in the wake of the Law, notably Kawasaki's 2017 ordinance prohibiting the use of parks and other public amenities to demonstrators engaging in acts likely to incite violence. While it has been argued that the Kawasaki enactment, whose text clearly shows the influence of the 2016 Law, does not constitute a direct ban on hate speech rallies, the policy it frames appears to have deterred such demonstrations, something that Wolman suggests is evidence of the extralegal impact of the Hate Speech Law [49: 99].

This brings us back to the question of the illocutionary and legal force of a law whose Ideational, Interpersonal and Textual features evoke policy statements rather than legislation. While Higaki [3: 245] links the text to an established legal strategy developed in the United States that allows authorities to give legal weight to policy opinions without being accused of violating constitutional constraints, it could also be argued that despite a failure to criminalise hate speech it has had an impact in several areas. These include local-level initiatives such as the Kawasaki ordinance; supplementary resolutions passed by the Diet to clarify and arguably extend the Law's ambit; and an increase in discussions about minority rights that are explicit in its provisions on educational activities. The measure has established an institutional framework for regular meetings between the Ministry of Justice and local authorities that have produced a nationwide survey of racial and ethnic discrimination [48] and a series of nationwide publicity campaigns that involved the display of "Stop hate speech!" banners at sports matches [50].

Higaki [3: 238] and others have portrayed the Law as unusual because of its lack of penalties, but it is hardly a legislative outlier. Together with a tradition of granting wide discretionary powers to both national and local authorities that amounts to a significant influence over policy implementation, there have been a number of Japanese laws whose role is more one of policy indicator than penalty-backed regulator. These include air pollution controls introduced in 1993 [51] and the 1986 Equal Employment Opportunities Law, which required that employers strive to eliminate gender discrimination but did not impose penalties for failure to do so [52]. While 
caution is always advisable in essentialised portrayals of Japanese law as consensusoriented and favouring persuasion over coercion, it is not too much to say that the didactic and paternalistic role of national and local government remains a significant factor in policy implementation there, and in this light the capacity of the 2016 Law to reduce hate speech, protect groups of people other than those envisaged in the original draft, and promote awareness of discrimination in the way proposed, will depend rather more on the strength of political commitment to diversity than on the wording of the legal text itself. So far the law seems to have had little impact on online hate speech, but here too there are signs that the way forward preferred by political authorities will be through persuasion rather than coercion: one year before the Hate Speech Law was promulgated a video streaming website shut down the official channel of Zaitokukai on the grounds that it had violated public order and morals, without going into specific details [53], a response invoking social normativisation rather than regulatory violation that accords with the semiotic orientation embedded in the Hate Speech Law.

Supplementary Information The online version contains supplementary material available at https://doi. org/10.1007/s11196-022-09883-9.

\section{References}

1. e-Gov法令検索 Hōrei Kensaku. 2021. Database of Japanese constitution, legislation and government, prefectural and ministerial ordinances) https://elaws.e-gov.go.jp/document?lawid=428AC 1000000068

2. Shimbun, Nihon Keizai. 2017. 法務省、ヘイトスピーチの具体例を提示 (Justice Ministry offers concrete examples of hate speech). https://www.nikkei.com/article/DGXLASDG04H53_U7A20 0C1CR8000/

3. Higaki Shinji. 2021. Hate Speech Elimination Act: a legal analysis. In Hate Speech in Japan. The possibility of a non-regulatory approach, ed. Shinji Higaki \& Yuji Nasu, pp. 237-256

4. The Japan Times. 2017. Make hate speech law stronger. https://www.japantimes.co.jp/opinion/2017/ 06/10/editorials/make-hate-speech-law-stronger/

5. Halliday, M.A.K. 1989. Context of Situation. In Language,context and text: aspects of language in a social-semiotic context, ed. M.A. K Halliday \& Ruqaiya Hassan. Oxford: OUP.

6. Fairclough, Norman. 1993. Critical discourse analysis and the marketization of public discourse: The universities. Discourse and Society 4 (2): 133-168.

7. Chik, Sonia. 2018. Towards a systemic functional contrastive analysis of Japanese and English corporate legal discourse. In Fontaine Perspectives from systemic functional linguistics, ed. Akila S. Baklouti \& Lise. London \& New York: Routledge. DOI: https://doi.org/10.4324/9781315299 877-10.

8. Bhatia, Vijay. 1996. Methodological issues in genre analysis. Hermes Journal of Linguistics 16-1996: 39-60.

9. Martin, J.R., M. Zappavigna, P. Dwyer, and C. Cleirigh. 2013. Users in uses of language: Embodied identity in youth justice conferencing. Text \& Talk 33 (4/5): 467-496.

10. Halliday, M.A.K. 1985. An introduction to functional grammar. London: Arnold.

11. Thompson, Geoff. 2014. Introducing functional grammar. London: Routledge.

12. Halliday, M.A.K. 1994. An introduction to functional grammar. London: Edward Arnold.

13. Jisho.org/. 2021. (Online Japanese-English dictionary)

14.「人前で言ったり,したりすること」https://dictionary.goo.ne.jp/word

15. Takeshi, Hashiuchi., Sachiko, Shudo., Migiwa, Ikebe. 2016. ヘイトスピーチ対策法の問題点を 考える(Considering problematic issues in the law against hate speech). Paper presented to Japan Law and Language Association colloquium, Waseda University, Tokyo. 
16. 弁護士法人心Kokoro, Bengoshi Hōjin . 2021. https://www.lawyers-kokoro.com/useful/others/ keiyakujoukou/

17. Kanpō. 官報 https://kanpou.npb.go.jp/ (National Printing Bureau).

18. Halliday, M.A.K. (revised by Christian Matthiesen). 2013. An Introduction to Functional Grammar. Routledge.

19. Bilewicz, Michał \& Soral, Wiktor. 2020. Hate speech epidemic. The dynamic effects of derogatory language on intergroup relations and political radicalization. Advances in Political Psychology, June 2020.

20. Yamamoto, Kana. 2015. The Myth of "Nihonjinron", homogeneity of Japan and its influence on the society. In Working Paper. Mapping Global Racisms, Leeds University Centre for Ethnicity and Racism Studies. https://cers.leeds.ac.uk/mapping-global-racisms/

21. Lee, Min Jeong. 2021.10.18. Hate speech case forces Japan to confront workplace racism. The Japan Times. https://www.japantimes.co.jp/news/2021/10/18/national/hate-speech-racism/

22. Shimazu, Naoko. 1998. Japan, race and equality. The racial equality proposal of 1919. Abingdon: Routledge.

23. Takayo, Inoue, and Ito Takehiko. 1993. Acculturalization problems for foreigners in Japan. Japanese Health and Psychology 1993 (2): 64-74.

24. Toshiyuki, Tamura. 2003. The status and role of ethnic Koreans in the Japanese economy. In The Korean diaspora in the world economy ed. C. Fred Bergsten \& Inbom Choi, 77-97. Washington, D.C: Institute for International Economics.

25. Ryang, Sonia, Cited in Jang Hawon. 2019. The special permanent residents in Japan: Zainichi Korean. Yale Review of International Studies, January 2019. http://yris.yira.org/comments/2873

26. Immigration Services Agency, Ministry of Justice website. http://www.moj.go.jp/isa/content/93000 6067.pdf

27. Robillard-Martel, Xavier, and Christopher Laurent. 2019. From colonization to Zaitokukai: The legacy of racial oppression in the lives of Koreans in Japan. Asian Ethnicity. https://doi.org/10.1080/ 14631369.2019.1575718.

28. Jang Hawon, 2019. The special permanent residents in Japan: Zainichi Korean. Yale Review of International Studies, January 2019. http://yris.yira.org/comments/2873

29. Murawaki, Yūgo. 2019. Origin of South Korea's anti-rising sun flag campaigns. http://murawaki. org/misc/flag.html

30. Yeo Jun-suk. 2018. Rising sun flag versus Dokdo ship: controversy over naval festival. In The Korean Herald. http://www.koreaherald.com/view.php?ud=20181004000538

31. Chan, Che-po, and Brian Bridges. 2006. China, Japan and the clash of nationalisms. Asian Perspective 30 (1): 127-156.

32. Asashi, Shimbun. 2020.「国籍差別, 日本は変わったか 50年前のきょう, 19歳がある裁判を起 こした」(Nationality-based discrimination - has Japan changed? One 19-year-old's lawsuit from 50 years ago today.). https://www.asahi.com/articles/DA3S14724390.html?iref=pc_ss_date_article

33. Yoon, Sharon J., and Yuki Asahina. 2021. The rise and fall of Japan's new far right: How AntiKorean discourses went mainstream. Politics and Society 49 (3): 363-402.

34. Kyōto, Shimbun. 2019.「なぜ在日コリアン嫌うのか?「ニンジン嫌いと一緒」.元在特会メ ンバーら, 朝鮮学校へイトに謝罪なし」(Why hate Koreans? "It's like hating carrots”. Former Zaitokukai members fail to apologise for Korean school hate.). https://www.kyoto-np.co.jp/artic les/-/100709

35. Kawanishi, Akihiro. 2018. 日本におけるへイトスピ 一チ規制——イトスピ 一千解消法 をめぐって (Hate Speech Regulation in Japan: concerning the Hate Speech Elimination Law). レ ファレンス (The Reference) 2018.4, 807, 51-73. 国立 国会図書館 National Diet Library.

36. Shimbun, Asahi . 2020. 朝鮮学校に響いた罵声 元児童ら7割「今も恐怖感じる」(Echoes from Korean school: $70 \%$ of former pupils still in fear.). https://www.asahi.com/articles/ASN6H54C9N 5WUTIL04Q.html

37. Shizuoka District Court, Hamamatsu (Ana Bortz) 平成 10 年(ワ)第 332 号, decided 12 October 1999.

38. The Japan Times. 2016. High court doubles damages owed by anti-Korean group, labels attack against Japanese as racist. https://www.japantimes.co.jp/news/2016/04/25/national/high-court-doubl es-damages-owed_- anti-korean-group-labels-attack-japanese-racist/.

39. Osaki, Tomohiro. 2016. Diet passes Japan's first law to curb hate speech. The Japan Times. https://www.japantimes.co.jp/news/2016/05/24/national/social-issues/ diet-passes- japans-first-law-curb-hate-speech/. 
40. 日本臣民八法律ノ範囲内二於テ言論著作印行集会及結社ノ自由ヌ有ス」 Imperial Constitution. 1890. https://www.ndl.go.jp/constitution/etc/j02.html

41. Satō, Junichi. 2017. ヘイトスピーチ規制の法的問題点 憲法と国際人権法の視 点から (Legal issues of hate speech regulation from the perspective of the constitution and international human rights law). 国際人権広場no. 133 (2017.5号), 一般財団法人アジア・太平洋人権情報センター (Asia Pacific Human Rights Information Center). https://www.hurights.or.jp/archives/newsletter/ section4/2017/05/post-13.html.

42. The Japan Times. 2019. Former senior member of Zaitokukai fined $¥ 500,000$, but escapes prison term over anti-Korean hate speech. https://www.japantimes.co.jp/news/2019/11/30/national/crimelegal/zaitokukai-fine -prison-anti-kore-hate-speech/.

43. Ichikawa Masato. 2003. 表現の自由の法理 Freedom of expression and Courts. Tokyo: Nippon Hyōron Sha.

44. Lepoutre, Maxime Charles. 2019. Can more speech counter ignorant speech? Journal of Ethics and Social Philosophy. https://doi.org/10.26556/jesp.v16i3.682.

45. Kotani, Junko. 2018. Proceed with caution. Hate speech regulation in Japan. Hastings Constitutional Law Quarterly 45 (3): 603-621.

46. See, for example, the 1990 Supreme Court ruling on political broadcasting:「政見放 送削除事件 判決」(最高裁判決平成2年4月17日)

47. Provisional translation available on Ministry of Justice website at www.moj.go.jp/content/00119 9551

48. The Mainichi. 2017. Editorial: To end hate speech Japan must face its deep- rooted discriminatory thinking. https://mainichi.jp/english/articles/20170608/p2a/00m/0na/019000c

49. Wolman, Andrew. 2019. Combating hate speech at the local level: A comparison of east Asian and European approaches. Nordic Journal of Human Rights 37 (2): 87-104. https://doi.org/10.1080/ 18918131.2019.1614255.

50. Inaugural Meeting of Human Rights Education and Awareness liaison Committee on Hate Speech Countermeasures, September. 2016. 人権教育・啓発中央省庁連絡協議会へイトスピーチ対策専 門部会 http://www.moj.go.jp/JINKEN/jinken04_00108.html.

51. Fujikura, Ryō. 2007. Administrative guidance of japanese local government for air pollution control. In Development of environmental policy in Japan and Asian countries, ed. Terao \& Ōtsuka. IDE-JETRO Series, London: Palgrave- Macmillan.

52. 雇用の分野における男女の均等な機会及び待遇の確保 等に関する法律施行 規則 The legislation has subsequently been strengthened but still relies on mediation rather than coercion.

53. The Japan Times. 2015. Video posting site shuts down anti-Korean Zaitokukai activists' channel. https://www.japantimes.co.jp/news/2015/05/20/national/social-issues/video-posting-site-shuts -anti-korean-zaitokukai-activists-channel/

Publisher's Note Springer Nature remains neutral with regard to jurisdictional claims in published maps and institutional affiliations. 